\title{
Serum amino terminal type III procollagen peptide and serum hyaluronan in rheumatoid arthritis: relation to clinical and serological parameters of
} inflammation during 8 and 24 months' treatment with levamisole, penicillamine, or azathioprine

\author{
K HØRSLEV-PETERSEN, ${ }^{1}$ K D BENTSEN, ${ }^{1}$ \\ A ENGSTRÖM-LAURENT ${ }^{2}$ P JUNKER, ${ }^{1}$ P HALBERG, ${ }^{1}$ AND \\ I LORENZEN
}

From the 'Department of Medicine, Division of Rheumatology, University of Copenhagen, Hvidovire Hospital, DK-2650 Hvidovre, Copenhagen, Denmark; and the ${ }^{2}$ Department of Medicine, Division of Rheumatology, University Hospital, S-751 85 Uppsala, Sweden

SUMMARY Increased serum levels of the amino terminal type III procollagen peptide and serum hyaluronan were demonstrated in patients with rheumatoid arthritis. In patients with active disease a significant correlation was shown between serum levels of the propeptide and hyaluronan and the clinical signs of synovitis reflecting the extent of synovial inflammation During recovery the serum propeptide and serum hyaluronan showed a delayed decline as compared with the clinical signs of synovitis and the acute phase protein response. This probati reflects the presence of persistent subclinical chronic inflammation. Normal serum propeptide levels in rheumatoid arthritis were associated with a good prognosis without progression of erosive joint lesions. Azathioprine reduced the number of patients with progression of erosis joint lesions and caused a more marked suppression of the serum propeptide than levamisole and penicillamine.

Key words: procollagen type III N-peptide, serum analyses, disease modifying antirheumatie drugs.

Measurement of the serum concentration of the procollagen metabolite, amino terminal type III procollagen peptide (PIIINP), ${ }^{12}$ and of the polysaccharide, hyaluronan (hyaluronic acid, HA), ${ }^{34}$ has made it possible to monitor changes in the metabolism of matrix constituents in acute and chronic fibrotic diseases. ${ }^{5}$

Assays for these metabolites have previously been carried out in patients with connective tissue diseases, including rheumatoid arthritis (RA) ${ }^{16-8}$ and systemic sclerosis. ${ }^{910}$

Cross sectional studies have shown that serum PIIINP (S-PIIINP) and serum HA (S-HA) reflect

Accepted for publication 14 August 1987.

Correspondence to Dr Hørslev-Petersen, Department of Medicine, Division of Rheumatology, University of Copenhagen. Hvidovre Hospital, DK-2650 Hvidovre, Copenhagen, Denmark. disease activity in RA. ${ }^{8}$ The inflamed synoviug seems to be the main source of increased S-PIIINP疋 A significant correlation has been shown between the acute phase proteins and S-PIIINP ${ }^{6}$ and $S-\mathrm{HA}_{\rightarrow}^{78}$ A preliminary prospective study showed thas S-PIIINP may be a useful prognostic marker 畐 RA. $^{6}$

In the present study the relation betweer S-PIIINP, S-HA, and the established clinical, biog chemical, and radiological variables reflecting syngvitis activity was evaluated during a two year, double blind trial of levamisole, penicillamine, and azathioprine in patients with RA. ${ }^{11-14}$ The purpose of the study was to compare the changes in the connective tissue metabolites with the clinical sige and the serological parameters of inflammation $\overrightarrow{0}$ find out whether S-PIIINP and S-HA had a prediefs 
tive value for clinical remission and progression of joint erosions, and to investigate the influence of drug treatment on the serological connective tissue metabolites.

\section{Patients and methods}

PATIENTS AND CONTROLS

Patients with active classical or definite RA according to the American Rheumatism Association criteria $^{15}$ were included in a 24 month trial of levamisole, penicillamine, and azathioprine. ${ }^{12}$ All patients had active synovitis fulfilling at least three of the following four criteria ${ }^{16}$ : three or more swollen joints, six or more tender joints, morning stiffness of 45 minutes' duration or more, and erythrocyte sedimentation rate (ESR) of $30 \mathrm{~mm} / \mathrm{h}$ or more. The exclusion criteria were as follows: functional class IV, ${ }^{17}$ age of 16 years or less, pregnancy, concurrent diseases with poor life expectancy, clinical sign of abnormal thyroid function, impaired liver function (S-aspartate aminotransferase $>40$ $\mathrm{U} / \mathrm{l}, \quad$ S-alkaline phosphatase $>275 \mathrm{U} / \mathrm{l}$, and S-bilirubin $>17 \mu \mathrm{mol} / \mathrm{l}$ ) or kidney function (S-creatinine $>120 \mu \mathrm{mol} / \mathrm{l}$ ), patients who refused to participate after receiving information about the trial, and patients who had received levamisole, penicillamine, azathioprine, cyclophosphamide, chloroquine, gold salts, or steroids within the last three months. The study was designed as a two year, double blind trial. Non-responders to treatment were withdrawn from the study after eight months.

Sixty six patients, 45 women and 21 men, aged 31-77 years (median 62 years) with a disease duration of 5-530 months (median 60) were included in the study. Fifty eight patients had erosive disease, and 61 were seropositive (Rose-Waaler test). Sixteen patients had extra-articular manifestations. All had subcutaneous rheumatoid nodules, two had pleurisy, and one polyneuropathy. There was no evidence of disturbed pulmonary function in the remaining patients. Twenty patients allocated to treatment with levamisole were given $50 \mathrm{mg}$ daily for one week, $100 \mathrm{mg}$ daily on the following week, and $150 \mathrm{mg}$ daily as a maintenance dosage. Twenty four patients allocated to penicillamine received $150 \mathrm{mg}$ daily for three weeks. The dosage was raised by increments of $150 \mathrm{mg}$ every three weeks until a dosage of $600 \mathrm{mg}$ daily was reached. Twenty two patients allocated to azathioprine were given $2.5 \mathrm{mg}$ per kilogram body weight daily. All patients were given $1600 \mathrm{mg}$ ibuprofen daily. Other non-steroidal anti-inflammatory drugs were not allowed during the study.

Clinical evaluation of synovitis activity was performed by a 'blind' observer (the same rheumatologist throughout the study) at months $0,4,8$, and
$24 .^{11}$ The patients were questioned about the duration of morning stiffness. The total number of swollen and tender joints, corrected for joint size according to Lansbury, ${ }^{18}$ was recorded, and the average grip strength of both hands was measured. The following serological variables were measured at months $0,4,8$, and 24 : ESR, $C$ reactive protein (CRP), orosomucoid, haptoglobin, total IgG, IgM rheumatoid factors, IgG rheumatoid factors, ${ }^{19}$ and Clq. Circulating immune complexes were detected by two methods: complement consumption test ${ }^{20}$ and platelet aggregation test. ${ }^{21}$

The evaluations at month 4 were not performed in two of the patients who completed eight months of treatment. Serum analysis for $\mathrm{IgG}$ rheumatoid factors were missing in three patients at month 4 and eight patients at month 8 .

Radiological examinations were performed of eight regions (shoulders, elbows, wrists, hands, hips, knees, ankles, and feet) at months 0,8 , and 24 . The radiological changes in each region were graded as described previously. ${ }^{22}$ The grading was based on the most severe destructive changes of each region. In the first 34 patients, who completed eight months of treatment, the radiograms of the hands at months 0 and 8 were read separately, the individual joints being evaluated in detail. The number of joint erosions were counted and the narrowing of the joint spaces was graded. ${ }^{11}$ The radiograms from each patient were read at the same time by two radiologists who were unaware of the patients' data. Radiological examinations were omitted in two patients at month 0 and one patient at month 8 owing to incomplete radiograms.

The treatment was stopped owing to development of drug side effects within the first four months in six patients and during the next four months in another six patients. Between months 8 and 24 treatment was withdrawn owing to lack of treatment response, relapse of the disease, or side effects of drugs in 32 patients.

Control sera for determination of S-PIIINP were obtained from 56 healthy individuals, 30 women and 26 men, age $34-82$ years (median 52). S-HA was measured in 160 healthy individuals, 91 men and 69 women, age 31-80 years (median 46).

SERUM SAM PLES

Blood samples were collected between 9.00 am and $10.00 \mathrm{am}$. The blood samples were allowed to clot at room temperature and then centrifuged at $1500 \mathrm{~g}$ for 10 minutes. Aliquots were immediately frozen and stored at $-20^{\circ} \mathrm{C}$ for up to eight years.

ANALYTICAL PROCEDURE

PIIINP and its degradation products were determined by two radioimmunoassays: the RIA-gnost 
procollagen-III-peptide assay system and the Fabprocollagen-III-peptide assay system (Hoechst A G, Frankfurt, West Germany). Both assays were developed by Rohde et al. ${ }^{12}$ The analyses were performed as previously described. ${ }^{6}$ The intra-assay and interassay variations determined with a control reference serum were for the RIA-gnost assay (median $6.5 \mathrm{ng} / \mathrm{ml}$ ) $5 \%$ and $8 \%$ respectively, and for the Fab assay (median $53 \mathrm{ng} / \mathrm{ml}$ ) $5 \%$ and $9 \%$ respectively. Samples to be compared were run simultaneously, and the values given are means of duplicate determinations. Repetitive thawing, and freezing for up to six years did not influence the S-PIIINP measurements. The higher propeptide levels recorded with the Fab assay are due to a 10-20 times higher affinity of the propeptide degradation product, Col 1, to the antibodies used in the Fab assay, as compared with the antibodies in the RIAgnost technique. ${ }^{2}$

Recovery experiments were performed on serum using RIA-gnost and Fab PIIINP assays. The following components were added to $0.25 \mathrm{ml}$ of serum from eight healthy individuals and from eight patients with active seropositive rheumatoid arthritis included in the prospective study: $0.25 \mathrm{ml}$ of phosphate buffer $\mathrm{pH} 7 \cdot 2,0.25 \mathrm{ml}$ purified human propeptide, Col $1-3$, in phosphate buffer $\mathrm{pH} 7 \cdot 2$ (concentration in RIA-gnost assay $15.6 \mathrm{ng} / \mathrm{ml}$, in Fab PIIINP assay $24 \mathrm{ng} / \mathrm{ml}$ ), or $0.25 \mathrm{ml}$ human Col 1 in phosphate buffer $\mathrm{pH} 7 \cdot 2$ (concentration in RIAgnost assay $3.9 \mathrm{ng} / \mathrm{ml}$, in Fab PIIINP assay $53 \mathrm{ng} / \mathrm{ml}$ ). The aliquots were mixed, incubated at $4^{\circ} \mathrm{C}$ for 16 hours, and analysed.

Samples $(1-2 \mathrm{ml})$ were chromatographed by application on a column $(1.6 \times 90 \mathrm{~cm})$ of Sephacryl S-300 equilibrated in phosphate buffered saline $\mathrm{pH}$ 7.2 containing $0.05 \%$ Tween 20 , and elution at a flow rate of $14 \mathrm{ml} / \mathrm{h}$. Fractions of $1.9 \mathrm{ml}$ were collected. Each fraction was analysed for the presence of PIIINP immunoreactive material in the RIA-gnost and Fab PIIINP assay. The column was calibrated with labelled intact bovine propeptide, intact human Col 1-3, and human Col 1 . The elution volume of the column was determined with dinitrophenylalanine as indicator.

In the prospective study S-PIIINP analyses of one month 0 sample and three month 4 samples were not performed owing to lack of serum.

S-HA was determined by a radioassay for sodium hyaluronate using high affinity binding protein from bovine cartilage according to methods previously described. ${ }^{34}$ The intra-assay variation was $12 \%$ at a serum concentration of $20 \mu \mathrm{g} / \mathrm{l}$. All samples to be compared were run concurrently, and the values given are means of duplicate or triplicate determinations.
Owing to lack of samples, S-HA analyses we not performed on 11 samples at 0 months, four four months, four at eight months, and four at 24 months.

STATISTICAL ANALYSIS

Data are expressed as range and median. Tras statistical analyses were performed using the Man Whitney test, the Kruskal-Wallis $\chi^{2}$ test, and the Fisher exact probability test for unpaired data and the Wilcoxon test for paired data. ${ }^{23}$ For these analyses $p$ values $\leqslant 0.05$ (two tailed test) were considered significant. Owing to the distribution of S-HA and IgM rheumatoid factors, these resulo were transformed logarithmically before analysis with the Wilcoxon test for paired data. The correla tions were calculated using the Spearman correlar tion coefficient. ${ }^{23}$ To avoid type I error due multiple correlation analyses only correlations wi $p \leqslant 0.005$ (two tailed tests) were considered signifi. cant.

\section{Results}

In healthy control subjects S-PIIINP as measure $b \overrightarrow{b \Phi}$ the RIA-gnost assay (S-RIA-PIIINP) was 3.2-81 80 $\mathrm{ng} / \mathrm{ml}$ (median 6.4) and by the Fab assay (S-Fab PIIINP) 34-85 ng/ml (median 52). The normal fovel of S-HA was 12-172 $\mathrm{ng} / \mathrm{ml}$ (median 42).

In serum samples $88-116 \%$ (median 99) and $83-104 \%$ (median 92) of Col 1-3 added was rof covered using the RIA-gnost assay and Fab-PIIIN assay respectively, whereas $77-103 \%$ (median 9 (1) and $89-109 \%$ (median 98 ) of Col 1 added wås recovered using the RIA-gnost assay and Fa告 PIIINP assay respectively. No differences were observed in the recoveries of $\mathrm{Col} 1-3$ or $\mathrm{Col}$ : between sera from healthy controls or from patientक्ष with rheumatoid arthritis. No relation was show. between the recovery percentages of Col 1-3 or Col 1 and the serum concentrations of total IgG, IgM rheumatoid factors, IgG rheumatoid factors, Clq, or circulating immune complexes in the patients wi rheumatoid arthritis.

In the prospective study S-RIA-PIIINP, S-Fa酐 PIIINP, and S-HA levels at months 0,4 , and 8 wero significantly higher than in the healthy controds $(\mathrm{p}<0.001)$ (Table 1). An increase in S-Fab-PIIIN during the first four months was followed by decrease in S-RIA-PIIINP and S-Fab-PIIINP be tween months 4 and 8 (Table 1). S-HA decreased significantly between months 0 and 8 (Table 1)

The relation between the pooled observations at months 0,4 , and 8 of S-RIA-PIIINP, S-Fab-PIIINB; and S-HA are shown in Table 2. A correlation between S-RIA-PIIINP and S-Fab-PIIINP was seל़्री 
at each observation, whereas the correlation seen at month 0 between S-PIIINP and S-HA disappeared after four and eight months of treatment (Table 3).

The clinical and paraclinical variables at months 0,4 , and 8 are shown in Table 1 . These indicators of disease activity showed improvement within the first four months, followed by small changes in the same direction during the subsequent four months. No differences were recorded in the clinical signs of disease activity between the three treatment subgroups throughout the study.

Statistically significant correlations were demonstrated between the pooled observations at months 0,4 , and 8 of S-RIA-PIIINP, S-Fab-PIIINP, and S-HA, on the one hand and the tender and swollen joint indices, the grip strength, CRP, ESR, total IgG, and IgG rheumatoid factors, on the other hand (Table 2). No statistically significant correlations were observed between the pooled observations of S-RIA-PIIINP, S-Fab-PIIINP, and S-HA, on the one hand and morning stiffness, S-orosomucoid, S-haptoglobin, IgM rheumatoid factors, Clq, and circulating immune complexes, on the other hand.
Statistically significant correlations were observed at month 0 between the S-RIA-PIIINP, S-FabPIIINP, and S-HA and the tender and swollen joint indices, and CRP. These correlations disappeared after four and eight months of treatment (Table 3). No correlations were observed between the connective tissue related serum markers and morning stiffness, grip strength, ESR, S-orosomucoid, Shaptoglobin, total IgG, IgG rheumatoid factors, IgM rheumatoid factors, C1q, and circulating immune complexes at the individual observations at months 0,4 , and 8 .

No statistically significant differences were observed in S-RIA-PIIINP, S-Fab-PIIINP, or S-HA between patients with and without extra-articular manifestations. The three patients with extraarticular manifestations other than cutaneous nodules, however, i.e., the two patients with pleurisy and the patient with polyneuropathy, had S-RIA-PIIINP values above $19.7 \mathrm{ng} / \mathrm{ml}$ throughout the eight month study.

Fifty four patients completed the first eight months of treatment. The patients were then

Table 1 Clinical signs of synovitis, acute phase protein response, and serological connective tissue metabolites in rheumatoid arthritis during eight months of treatment with disease modifying antirheumatic drugs

\begin{tabular}{|c|c|c|c|c|c|c|c|c|c|c|c|c|}
\hline \multirow[t]{2}{*}{ Parameter } & \multicolumn{4}{|c|}{ Month 0} & \multicolumn{4}{|c|}{ Month 4} & \multicolumn{4}{|c|}{ Month 8} \\
\hline & $n^{*}$ & Range & Median & $\begin{array}{l}p \text { Valuet } \\
(0 \vee 4 \\
\text { months })\end{array}$ & $n$ & Range & Median & $\begin{array}{l}p \text { Value } \\
(4 \vee 8 \\
\text { months })\end{array}$ & $n$ & Range & Median & $\begin{array}{l}p \text { Value } \\
(0 \vee 8 \\
\text { inonths })\end{array}$ \\
\hline $\begin{array}{l}\text { S-RIA-PIIINP } \\
\text { (ng/ml) } \\
\text { S-Fab-PIIINP }\end{array}$ & 65 & $8 \cdot 0-37 \cdot 9$ & $16 \cdot 3$ & NS & 56 & $8 \cdot 4-31 \cdot 3$ & $16 \cdot 9$ & $0 \cdot 01$ & 54 & $8 \cdot 2-32 \cdot 3$ & $15 \cdot 6$ & NS \\
\hline $\begin{array}{c}(\mathrm{ng} / \mathrm{ml}) \\
\text { S-hyaluronan } \ddagger\end{array}$ & 65 & $41-182$ & 75 & 0.05 & 56 & $54-166$ & 83 & $0 \cdot 01$ & 54 & $45-146$ & 79 & NS \\
\hline$(\mathrm{ng} / \mathrm{ml})$ & 55 & $23-1045$ & 250 & NS & 55 & $45-1025$ & 210 & NS & 50 & $21-1325$ & 196 & $0 \cdot 05$ \\
\hline Tender joints & 66 & $17-198$ & 105 & $0 \cdot 001$ & 57 & $0-173$ & 76 & $0 \cdot 001$ & 54 & $0-173$ & 57 & $0 \cdot 001$ \\
\hline Swollen joints & 66 & $4-96$ & 37 & $0 \cdot 001$ & 57 & $0-81$ & 17 & $0 \cdot(001$ & 54 & $0-114$ & 10 & 0.001 \\
\hline $\begin{array}{l}x \text { Ray score } \\
\text { Grip strength }\end{array}$ & 64 & $1-39$ & 10 & - & - & - & - & - & 53 & $0-39$ & 12 & $0 \cdot 001$ \\
\hline $\begin{array}{l}(\mathrm{mmHg}) \\
\text { Morning stiffness }\end{array}$ & 66 & $2 \cdot 0-61 \cdot 5$ & $13 \cdot 0$ & 0.001 & 57 & $0 \cdot 0-60 \cdot 5$ & $19 \cdot()$ & NS & 54 & $0 \cdot 5-83 \cdot 0$ & $19 \cdot 5$ & 0.001 \\
\hline$(\min )^{\circ}$ & 66 & $0-420$ & 120 & $0 \cdot 001$ & 57 & $0-270$ & 30 & $0 \cdot 001$ & 54 & $0-420$ & 15 & 0.001 \\
\hline $\operatorname{ESR}(\mathrm{mm} / \mathrm{h})$ & 66 & $12-126$ & 63 & $0 \cdot 001$ & 57 & $4-130$ & 31 & NS & 54 & $3-114$ & 31 & 0.001 \\
\hline $\begin{array}{l}\text { CRP }(\mathrm{mg} / \mathrm{l}) \\
\text { Orosomucoid }\end{array}$ & 66 & $0-1200$ & 340 & $0 \cdot 001$ & 57 & $0-730$ & 150 & NS & 54 & $0-750$ & 100 & $0 \cdot 001$ \\
\hline $\begin{array}{c}(\mu \mathrm{mol} / \mathrm{l}) \\
\text { Haptoglobin }\end{array}$ & 66 & $12-67$ & 38 & $0 \cdot 001$ & 57 & $12-48$ & 27 & NS & 54 & $14-55$ & 26 & 0.001 \\
\hline$(\mu \mathrm{mol} / \mathrm{l})$ & 66 & $15-88$ & 40 & $0 \cdot 001$ & 57 & $8-60$ & 25 & NS & 54 & $5-60$ & 24 & 0.001 \\
\hline $\operatorname{IgG}(g / 1)$ & 66 & $7 \cdot 4-27 \cdot 8$ & $13 \cdot 2$ & 0.001 & 57 & $7 \cdot 0-24 \cdot 0$ & $11 \cdot 7$ & $0 \cdot 05$ & 54 & $6 \cdot 2-24 \cdot 2$ & $11 \cdot 1$ & 0.001 \\
\hline IgM RF & 66 & $20-5120$ & 320 & NS & 57 & $20-5120$ & 320 & NS & 54 & $20-5120$ & 160 & NS \\
\hline IgG RF & 66 & $1 \cdot 0-15 \cdot 7$ & $5 \cdot 1$ & $0 \cdot 01$ & 54 & $1 \cdot 9-11 \cdot 8$ & $4 \cdot 6$ & $0 \cdot 05$ & 46 & $1 \cdot 3-8 \cdot 0$ & $4 \cdot 1$ & 0.001 \\
\hline $\mathrm{Clq}$ & 66 & $0 \cdot 5-1 \cdot 6$ & $1 \cdot 0$ & NS & 57 & $0 \cdot 5-1 \cdot 7$ & $1 \cdot 0$ & NS & 54 & $0.5-1 \cdot 6$ & $1 \cdot 0$ & NS \\
\hline
\end{tabular}

${ }^{*} n=$ number of patients.

†Statistics: Wilcoxon's test for paired data (two tailed); NS $=p>0.05$.

$\ddagger$ Normal range (median): S-RIA-PIIINP $3 \cdot 2-11 \cdot 8 \mathrm{ng} / \mathrm{ml}(6 \cdot 4 \mathrm{ng} / \mathrm{ml})$. S-Fab-PIIINP $34-85 \mathrm{ng} / \mathrm{ml}(52 \mathrm{ng} / \mathrm{ml}), \mathrm{S}$-hyaluronan $12-172 \mathrm{ng} / \mathrm{ml}$ $(42 \mathrm{ng} / \mathrm{ml})$. 
Table 2 Correlation between the pooled observations at months 0, 4, and 8 of serological parameters of connective tissue metabolites and clinical signs of synovitis and acute phase protein response in rheumatoid arthritis during treatment with disease modifying antirheumatic drugs

\begin{tabular}{|c|c|c|c|c|}
\hline \multirow[t]{2}{*}{ Parameter } & \multirow[t]{2}{*}{$n$} & \multicolumn{3}{|c|}{ Months $0+4+8$} \\
\hline & & $\begin{array}{l}\text { S-RIA- } \\
\text { PIIINP } \\
(n=177)\end{array}$ & $\begin{array}{l}S-F a b- \\
P I I I N P \\
(n=177)\end{array}$ & $\begin{array}{l}\text { S-hya- } \\
\text { luronan } \\
(n=160)\end{array}$ \\
\hline S-RIA-PIIINP & 177 & - & $\begin{array}{l}0 \cdot 69 \\
0 \cdot 0001\end{array}$ & $\begin{array}{l}0.31 \\
0.0001\end{array}$ \\
\hline S-Fab-PIIINP & 177 & $\begin{array}{l}0.69^{*} \\
0.0001+\end{array}$ & - & $\begin{array}{l}0.25 \\
0.002\end{array}$ \\
\hline S-hyaluronan & 160 & $\begin{array}{l}0 \cdot 31 \\
0 \cdot 0001\end{array}$ & $\begin{array}{l}0 \cdot 25 \\
0 \cdot 002\end{array}$ & - \\
\hline Tender joints & 177 & $\begin{array}{l}0.37 \\
0.0001\end{array}$ & $\begin{array}{l}0 \cdot 33 \\
0 \cdot 0001\end{array}$ & $\begin{array}{l}0.29 \\
0.0002\end{array}$ \\
\hline Swollen joints & 177 & $\begin{array}{l}0.24 \\
0.002\end{array}$ & $\begin{array}{l}0 \cdot 21 \\
0 \cdot 005\end{array}$ & $\begin{array}{l}0 \cdot 33 \\
0 \cdot 0001\end{array}$ \\
\hline Grip strength & 177 & $\begin{array}{l}-0 \cdot 26 \\
0 \cdot 0005\end{array}$ & $\begin{array}{l}-0 \cdot 12 \\
\text { NS }\end{array}$ & $\begin{array}{l}-0 \cdot 13 \\
\text { NS }\end{array}$ \\
\hline CRP & 177 & $\begin{array}{l}0.22 \\
0.005\end{array}$ & $\begin{array}{l}0 \cdot 12 \\
\text { NS }\end{array}$ & $\begin{array}{l}0.34 \\
0.0001\end{array}$ \\
\hline ESR & 177 & $\begin{array}{l}0 \cdot 20 \\
N S\end{array}$ & $\begin{array}{l}0 \cdot 10 \\
\text { NS }\end{array}$ & $\begin{array}{l}0 \cdot 26 \\
0 \cdot 001\end{array}$ \\
\hline IgG (total) & 177 & $\begin{array}{l}0.28 \\
0 \cdot 0002\end{array}$ & $\begin{array}{l}0 \cdot 29 \\
0 \cdot 0001\end{array}$ & $\begin{array}{l}0 \cdot 20 \\
\text { NS }\end{array}$ \\
\hline IgG RF & 166 & $\begin{array}{l}0.27 \\
0.0005\end{array}$ & $\begin{array}{l}0 \cdot 13 \\
\text { NS }\end{array}$ & $\begin{array}{l}0 \cdot 12 \\
\text { NS }\end{array}$ \\
\hline
\end{tabular}

*Spearman's $\mathrm{Q}$ value (two tailed test).

tp Value; $N S=p>0 \cdot 005$. divided into responders and non-responders. Non responders $(\mathrm{n}=30)$ still fulfilled the inclusion criterif for synovitis activity, whereas the responder's $(n=24)$ no longer fulfilled these criteria. One nons responder was excluded, because the initial serum sample was missing. No differences were foung between responders and non-responders in the changes of the serological connective tissue vari ables within the first four months, whereas significant reduction of S-RIA-PIIINP was seen in responders as compared with non-responder 9 between months 0 and 8 (responders -15.5 to $8 \cdot \overrightarrow{3}$ $\mathrm{ng} / \mathrm{ml}$ (median $-2 \cdot 1)$, non-responders $-9 \cdot 6$ to $15 \cdot 5$ $\mathrm{ng} / \mathrm{ml}$ (median 1.8); $<<0.02$ ), and of S-HA betwee months 4 and 8 (responders -560 to $379 \mathrm{ng} / \mathrm{mf}$ (median -106), non-responders -286 to $400 \mathrm{ng} / \mathrm{mN}$ (median -12); $\mathrm{p}<0 \cdot 05$ ).

To assess the prognostic value of S-PIIINP and $\mathrm{S}-\mathrm{HA}$ we calculated the correlations between tho initial S-RIA-PIIINP, S-Fab-PIIINP, or S-HA and the clinical synovitis scorings as well as the acuten phase proteins at months 4 and 8 , and the changes i these variables between months 0 and 8 . None of th correlations were significant at a level of $p \leqslant 0 \cdot 005 \frac{2}{z}$

A significant decrease in S-RIA-PIIINP waङ shown in the 19 patients treated with azathiop? during months $0-8(-9.6$ to $3.4 \mathrm{ng} / \mathrm{ml}$ (medfan $-1.9)$ ) as compared with the change in S-R PIIINP in the 34 patients treated with levamisole or penicillamine during months $0-8 \quad(-16 \cdot 1$ t

Table 3 Correlation between serological parameters of connective tissue metabolites and clinical signs of synovitis and acute phase protein response in rheumatoid arthritis after 0,4 , and 8 months of treatment with disease modifying antirheumatic drugs

\begin{tabular}{|c|c|c|c|c|c|c|c|c|c|}
\hline \multirow[t]{2}{*}{ Parameter } & \multicolumn{3}{|l|}{ Month 0} & \multicolumn{3}{|l|}{ Month 4} & \multicolumn{3}{|l|}{ Month 8} \\
\hline & $\begin{array}{l}S-R I A- \\
P I I I N P \\
(n=65)\end{array}$ & $\begin{array}{l}\text { S-Fab- } \\
\text { PIIINP } \\
(n=65)\end{array}$ & $\begin{array}{l}\text { S-hya- } \\
\text { luronan } \\
(n=55)\end{array}$ & $\begin{array}{l}\text { S-RIA- } \\
\text { PIIINP } \\
(n=56)\end{array}$ & $\begin{array}{l}S-F a b- \\
P I I I N P \\
(n=56)\end{array}$ & $\begin{array}{l}\text { S-hya- } \\
\text { luronan } \\
(n=55)\end{array}$ & $\begin{array}{l}S-R I A- \\
P I I I N P \\
(n=54)\end{array}$ & $\begin{array}{l}\text { S-Fab- } \\
\text { PIIINP } \\
(n=54)\end{array}$ & $\begin{array}{l}\text { S-hya- } \\
\text { luronan } \\
(n=50)\end{array}$ \\
\hline \multirow[t]{2}{*}{ S-RIA-PIIINP } & - & $0.61^{*}$ & 0.45 & - & 0.82 & 0.19 & - & $(0 \cdot 70$ & 0.24 \\
\hline & - & $0.0001+$ & $0 \cdot 0005$ & - & 0.0001 & NS & - & $0 \cdot 0001$ & \\
\hline \multirow[t]{2}{*}{ S-Fab-PIIINP } & 0.61 & - & 0.45 & 0.82 & - & $0 \cdot 13$ & $0 \cdot 70$ & - & $0 \cdot 21$ \\
\hline & $0 \cdot 0(0) 1$ & - & $0 \cdot 00005$ & 0.0001 & - & NS & $0 \cdot(0001$ & - & NS \\
\hline \multirow[t]{2}{*}{ S-hyaluronan } & 0.45 & 0.45 & - & 0.19 & 0.13 & - & $(0.24$ & 0.21 & - \\
\hline & 0.00005 & $0 \cdot 0005$ & - & NS & NS & - & NS & NS & - \\
\hline \multirow[t]{2}{*}{ Tender joints } & 0.53 & 0.46 & 0.46 & 0.28 & 0.31 & $0 \cdot 15$ & 0.25 & 0.29 & 0.24 \\
\hline & $0 \cdot 0001$ & $0 \cdot 0001$ & $0 \cdot 0004$ & NS & NS & NS & NS & NS & NS \\
\hline \multirow[t]{2}{*}{ Swollen joints } & 0.38 & $0 \cdot 31$ & 0.37 & $0 \cdot 15$ & $0 \cdot 24$ & 0.27 & $0 \cdot 13$ & $0 \cdot 16$ & $0 \cdot 36$ \\
\hline & 0.002 & NS & $0 \cdot(005$ & NS & NS & NS & NS & NS & \\
\hline \multirow[t]{2}{*}{ CRP } & 0.31 & 0.43 & 0.44 & $0 \cdot 25$ & $0 \cdot 10$ & $0 \cdot 40$ & $0 \cdot 19$ & $-0 \cdot 11$ & $0 \cdot 11$ \\
\hline & NS & 0.0005 & 0.001 & NS & NS & 0.005 & NS & NS & NS \\
\hline \multirow[t]{2}{*}{ Orosomucoid } & $0 \cdot 21$ & $0 \cdot 19$ & 0.07 & $0 \cdot 18$ & 0.11 & $0 \cdot 36$ & $0 \cdot 13$ & $-(0 \cdot() 3$ & $0 \cdot(02$ \\
\hline & NS & NS & NS & NS & NS & 0.005 & NS & NS & NS \\
\hline \multirow[t]{2}{*}{$\operatorname{lgG}$} & 0.27 & 0.25 & 0.28 & $0 \cdot 34$ & 0.38 & $0 \cdot 25$ & $0 \cdot 19$ & 0.26 & $-0 \cdot(01$ \\
\hline & NS & NS & NS & NS & $0 \cdot(005$ & NS & NS & NS & NS \\
\hline
\end{tabular}


$15.0 \mathrm{ng} / \mathrm{ml}($ median $0 \cdot 2))(\mathrm{p}<0 \cdot 05)$. No differences were shown between the levamisole and the penicillamine groups. No differences were seen in the changes in S-Fab-PIIINP and S-HA between the treatment groups.

The relation of S-RIA-PIIINP to treatment, treatment duration, and response is shown in Table 4. In patients treated with levamisole and penicillamine a significant decrease of S-RIA-PIIINP was seen in responders compared with non-responders, whereas no difference was seen between responders and non-responders treated with azathioprine. The responders showed no changes of S-RIA-PIIINP related to treatment, whereas non-responders to azathioprine treatment had a significant decrease in S-RIA-PIIINP for months $0-4$ and $0-8$ as compared with the non-responders treated with levamisole or penicillamine. Similar calculations were performed with S-Fab-PIIINP and S-HA, but no relation could be found between these variables and treatment, treatment duration, and response.

There were no significant differences in S-RIAPIIINP, S-Fab-PIIINP, and S-HA at months $0,4,8$, or 24 between patients with progressive erosive joint changes and those without progression. Within the first eight months, however, only one of 11 patients with an average S-RIA-PIIINP (month $0+4+8$ ) within the normal range showed radiological evidence of progressive bone damage, whereas 17 of 39 patients with an average S-RIA-PIIINP above the normal range developed further bone destruction as shown by the general joint examinations. In the detailed evaluation of the hands none of seven patients with an average S-RIA-PIIINP within the normal range showed progressive bone erosions as compared with 12 of 27 patients with an average SRIA-PIIINP above the normal range, who developed further bone destruction. The two radiological evaluations (the general joint examination and the detailed evaluation of the hands) showed that none of seven patients with an average S-RIAPIIINP within the normal range developed new bone erosions as compared with 16 of 27 patients with an average S-RIA-PIIINP above the normal range, who developed further bone destruction $(\mathrm{p}<0.02)$ (Fig. 1). Between months 8 and 24 none of six patients with an average S-RIA-PIIINP (month $8+24)$ within the normal range developed further bone destructions as shown by examination of all the joints, whereas progression of bone damage was found in 10 of 16 patients with an average S-RIAPIIINP above the normal range $(\mathrm{p}<0 \cdot 05)$ (Fig. 1).

General joint examination and detailed evaluation of the hands showed that only two of 12 patients treated with azathioprine developed new joint erosions during the first eight months, as compared with 14 of 22 patients treated with levamisole or penicillamine $(\mathrm{p}<0.05)$.

Fifteen of 22 patients who completed 24 months' treatment fulfilled the remission criteria after eight and 24 months. A significant decrease in the clinical signs of synovitis and a normalisation in the acute

Table 4 Changes in the serum procollagen type III amino terminal peptide (S-RIA-PIIINP* based on analysis in the RIA-gnost procollagen-III-peptide assay) level in relation to treatment (azathioprine, levamisole, and penicillamine, Kruskal-Wallis (two tailed) test) and treatment response (non-responders still fulfilled the inclusion criteria for synovitis activity after eight months of treatment, whereas responders no longer fulfilled these criteria; Mann-Whitney (two tailed) test for unpaired data)

\begin{tabular}{|c|c|c|c|c|c|c|}
\hline \multirow[t]{2}{*}{ Treatment } & \multicolumn{3}{|l|}{$\Delta 4-()$ months } & \multicolumn{3}{|c|}{$\Delta 8-0$ months } \\
\hline & Responders & Non-responders & $\begin{array}{l}\text { Mann- } \\
\text { Whitney } \\
\text { p value }\end{array}$ & Responders & Non-responders & $\begin{array}{l}\text { Mann- } \\
\text { Whitney } \\
p \text { value }\end{array}$ \\
\hline Levamisole & & & $0 .(05$ & & & $0 \cdot(05$ \\
\hline No of paticnts & 8 & 6 & & 8 & 6 & \\
\hline Median & $1 \cdot 1$ & $2 \cdot 7$ & & $-1 \cdot 6$ & $2 \cdot 2$ & \\
\hline Range & $-10 \cdot 5-12 \cdot 7$ & $-4 \cdot 8-5 \cdot 9$ & & $-15 \cdot 5-8 \cdot 3$ & $0 \cdot 1-5 \cdot 2$ & \\
\hline Penicillaminc & & & 0.015 & & & $(0 \cdot 0) 1$ \\
\hline No of patients & 12 & 6 & & 13 & 7 & \\
\hline Median & -()$\cdot 2$ & $5 \cdot 3$ & & $-2 \cdot()$ & $3 \cdot 2$ & \\
\hline Range & $-7 \cdot 2-4 \cdot 9$ & $-2 \cdot 2-11 \cdot 6$ & & $-16 \cdot 1-5 \cdot 1$ & $-4 \cdot 9-15 \cdot()$ & \\
\hline Azathioprinc & & & NS ${ }^{\dagger}$ & & & NS \\
\hline No of paticnts & 9 & 10 & & 9 & 10 & \\
\hline Median & $-2 \cdot 7$ & $-1 \cdot 3$ & & $-1 \cdot 8$ & -1.9 & \\
\hline Rangc & $-6 \cdot 3-4 \cdot 6$ & $-2 \cdot 8-2 \cdot 8$ & & $-7 \cdot 5-1 \cdot 4$ & $-9 \cdot 7-3 \cdot 4$ & \\
\hline Kruskal-Wallis p value & NS & 0.05 & & NS & 0.122 & \\
\hline
\end{tabular}

Values of $S$-RIA-PIIINP in $\mathrm{ng} / \mathrm{ml}$.

$\div \mathrm{NS}=\mathrm{p}>0(1) \cdot(5$. 
phase proteins were seen during the first eight months. A small, but significant additional decrease was shown in the swollen and tender joint indices between months 8 and 24, whereas no changes were observed in the acute phase proteins (Table 5). No statistically significant changes were demonstrated in the serological connective tissue parameters within the first eight months, whereas all three markers showed decreasing levels after two years of treatment (Table 5). Only the changes in S-RIAPIIINP and S-HA were statistically significant, however. No statistically significant correlations were seen between S-RIA-PIIINP, S-Fab-PIIINP,
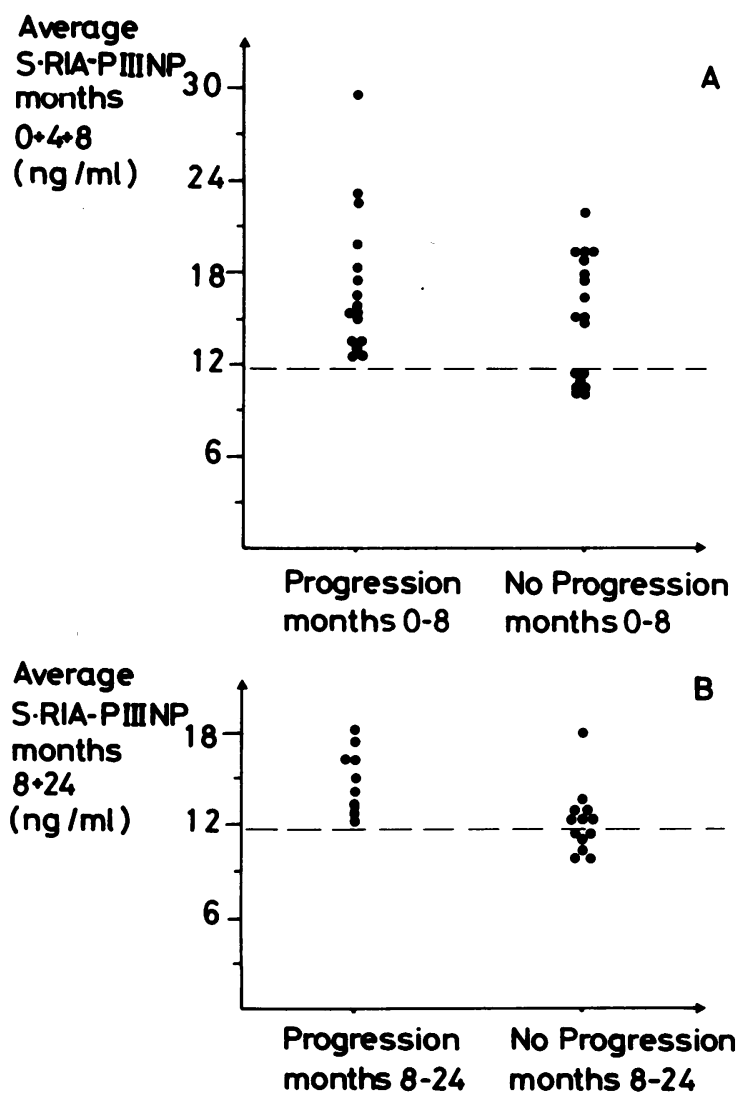

Fig. 1 Average serum procollagen type III amino terminal peptide (S-RIA-PIIINP based on analysis in the RIA-gnost procollagen-III-peptide assay) level in relation to development of new joint erosions. $A=$ average $S-R I A-P I I N P$ months $0+4+8$ in relation to progressive bone damage months $0-8$ evaluated by general joint examination and detailed hand evaluation; $B=$ average $S-R I A-P I I N P$ months $8+24$ in relation to progressive bone damage months 8-24 evaluated by general joint examination. Stippled lines indicate upper normal range. and S-HA and the clinical signs of synovitis or the acute phase proteins after 24 months of treatmene

Serum samples from a woman, age 60 , with erosive seropositive classical RA of 13 years duration were subjected to molecular exclusiog chromatography on a Sephacryl S-300 colum before and after eight and 24 months of azathioprin $\overline{\bar{s}}$ treatment. The acute phase reactants normalise within the first four months, whereas the clinical variables and the serological connective tissue metabolites improved throughout the two years of observation (S-RIA-PIIINP, month 0: $23.4 \mathrm{ng} / \mathrm{mL}$

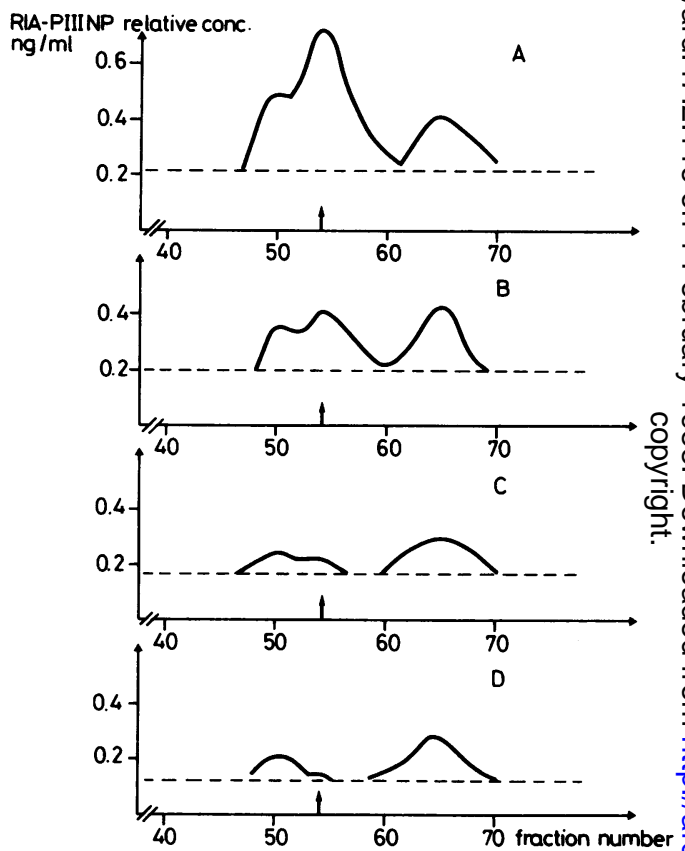

Fig. 2 Chromatography on a Sephacryl S-300 column $(1.6 \times 90 \mathrm{~cm}$, elution flow rate $14 \mathrm{ml} / \mathrm{h}$, collected fractions $1.9 \mathrm{ml}$ ) of serum samples from a 60 year old woman with active rheumatoid arthritis treated with azathioprine for 24 months. A=0 month (S-RIA-PIIINP $23.4 \mathrm{ng} / \mathrm{ml}$, $S$-Fab-PIIINP $78 \mathrm{ng} / \mathrm{ml}$ ), $B=8$ months (S-RIA-PIIINP $15.9 \mathrm{ng} / \mathrm{ml}, S$-Fab-PIIINP $62 \mathrm{ng} / \mathrm{ml}), C=24$ months (S-RIA-PIIINP $9.8 \mathrm{ng} / \mathrm{ml}$, S-Fab-PIIINP $48 \mathrm{ng} / \mathrm{ml}$ ), and $D=a 44$ year old apparently healthy woman (S-RIA-PIIINP $4.9 \mathrm{ng} / \mathrm{ml}, S$-Fab-PIIINP $40 \mathrm{ng} / \mathrm{ml}$ ). The $\mathrm{N}$ position of the radioiodinated standard procollagen type IIR amino terminal peptide (PIIINP) is indicated by an arrow. The relative concentration of the inhibitor in the different fractions was calculated using an RIA-gnost assay with the standard PIIINP as reference. The elution of human propeptide, Col 1-3, degraded human propeptide, Col 1, and dinitrophenylalanine corresponded to fractions 53, 65, and 122 respectively. Stippled lines indicate the lower detection limit in the RIA-gnost procollagen-III-peptide assay. 
Table 5 Clinical signs of synovitis, acute phase protein response, and serological connective tissue metabolites in patients with rheumatoid arthritis responding to two years of treatment with disease modifying antirheumatic drugs

\begin{tabular}{|c|c|c|c|c|c|c|c|c|c|c|c|c|}
\hline \multirow[t]{2}{*}{ Parameter } & \multicolumn{4}{|c|}{ Month 0} & \multicolumn{4}{|c|}{ Month 8} & \multicolumn{4}{|c|}{ Month 24} \\
\hline & $n^{*}$ & Range & Median & $\begin{array}{l}p \text { Valuet } \\
(0 \vee 8 \\
\text { months })\end{array}$ & $n$ & Range & Median & $\begin{array}{l}p \text { Value } \\
(8 \text { v } 24 \\
\text { months })\end{array}$ & $n$ & Range & Median & $\begin{array}{l}p \text { Value } \\
(0 \text { v } 24 \\
\text { months })\end{array}$ \\
\hline \multirow{3}{*}{$\begin{array}{l}\text { S-RIA-PIIINP } \ddagger \\
\text { (ng/ml) } \\
\text { S-Fab-PIIINP } \ddagger \\
\text { (ng/ml) } \\
\text { S-hyaluronan } \ddagger \\
\quad(\mathrm{ng} / \mathrm{ml})\end{array}$} & 15 & $9 \cdot 0-34 \cdot 4$ & $15 \cdot 1$ & NS & 15 & $9 \cdot 9-20 \cdot 3$ & $14 \cdot 1$ & $0 \cdot 05$ & 15 & $9 \cdot 8-16 \cdot 3$ & $11 \cdot 6$ & 0.02 \\
\hline & 15 & $44-182$ & 73 & NS & 15 & $45-146$ & 76 & NS & 15 & $45-100$ & 58 & NS \\
\hline & 14 & $23-800$ & 285 & NS & 12 & $88-540$ & 168 & NS & 11 & $50-520$ & 124 & 0.05 \\
\hline \multirow{4}{*}{$\begin{array}{l}\text { Tender joints } \\
\text { Swollen joints } \\
\text { Grip strength } \\
\text { (mmHg) } \\
\text { Morning stiffness } \\
\text { (min) }\end{array}$} & 15 & $41-160$ & 85 & $0 \cdot 01$ & 15 & $2-151$ & 27 & $0 \cdot 01$ & 15 & $0-126$ & 1 & $0 \cdot 01$ \\
\hline & 15 & $8-96$ & 31 & 0.01 & 15 & $0-27$ & 1 & $0 \cdot 05$ & 15 & $0-13$ & 0 & 0.01 \\
\hline & 15 & $6 \cdot 5-61 \cdot 5$ & $14 \cdot 5$ & $0 \cdot 05$ & 15 & $5 \cdot 0-83 \cdot 0$ & $33 \cdot 0$ & NS & 15 & $0 \cdot 0-85 \cdot 0$ & $36 \cdot 5$ & 0.05 \\
\hline & 15 & $15-390$ & 90 & $0 \cdot 01$ & 15 & $0-60$ & 0 & NS & 15 & $0-45$ & 0 & 0.01 \\
\hline \multirow{4}{*}{$\begin{array}{l}\text { ESR }(\mathrm{mm} / \mathrm{h}) \\
\text { CRP }(\mathrm{mg} / \mathrm{l}) \\
\text { Orosomucoid } \\
(\mu \mathrm{mol} / \mathrm{l}) \\
\text { Haptoglobin } \\
(\mu \mathrm{mol} / \mathrm{l})\end{array}$} & 15 & $12-103$ & 44 & 0.01 & 15 & $3-38$ & 19 & NS & 15 & $4-32$ & 16 & 0.01 \\
\hline & 15 & $0-730$ & 280 & $0 \cdot 01$ & 15 & $0-360$ & 0 & NS & 15 & $0-260$ & 10 & 0.01 \\
\hline & 15 & $16-51$ & 36 & $0 \cdot 05$ & 15 & $14-45$ & 20 & NS & 15 & $15-26$ & 20 & 0.05 \\
\hline & 15 & $17-88$ & 37 & $0 \cdot 01$ & 15 & $5-30$ & 15 & NS & 15 & $3-63$ & 17 & 0.01 \\
\hline
\end{tabular}

${ }^{*} \mathrm{n}=$ number of patients.

†Statistics: Wilcoxon's test for paired data (two tailed); NS $=p>0 \cdot 05$.

†Normal range (median): S-RIA-PIIINP $3 \cdot 2-11 \cdot 8 \mathrm{ng} / \mathrm{ml}(6 \cdot 4 \mathrm{ng} / \mathrm{ml})$, S-Fab-PIIINP $34-85 \mathrm{ng} / \mathrm{ml}(52 \mathrm{ng} / \mathrm{ml})$, S-hyaluronan $12-172 \mathrm{ng} / \mathrm{ml}$ $(42 \mathrm{ng} / \mathrm{ml})$.

month 8: $15.9 \mathrm{ng} / \mathrm{ml}$, month 24: $9.8 \mathrm{ng} / \mathrm{ml}$; S-FabPIIINP, month 0: $78 \mathrm{ng} / \mathrm{ml}$, month $8: 62 \mathrm{ng} / \mathrm{ml}$, month 24: $48 \mathrm{ng} / \mathrm{ml}$ ). The chromatograms showed three peaks containing PIIINP immunoreactive material (Fig. 2). A fraction corresponding to the intact propeptide, Col 1-3, dominated before treatment. As the acute inflammation subsided the Col 1-3 fraction, and to some extent the high molecular weight fraction, was reduced. The three fractions had almost equal activity after eight months. After 24 months the antigen size distribution was similar to that seen in normal serum showing the lowest activity in the Col 1-3 fraction and the highest activity in the Col 1 fraction. No alterations were seen in the Col 1 concentration throughout the observation period. For comparison a chromatogram of a serum sample from a healthy woman, age 44 (S-RIA-PIIINP $4.9 \mathrm{ng} / \mathrm{ml}$, S-Fab-PIIINP $40 \mathrm{ng} / \mathrm{ml}$ ), is shown. No additional peaks containing PIIINP immunoreactive material were detected by the Fab-PIIINP assay in any of the sera.

\section{Discussion}

It has been suggested that measurement of S-PIIINP may be a useful monitor of disease activity in various fibrotic diseases. ${ }^{54}$ The increase in S-PIIINP reflects the collagen type III synthesis and fibrillogenesis in developing granulation tissue. ${ }^{25}$ The inflamed synovium in RA is characterised by such a stimulated synthesis and accumulation of collagen type III. $^{26-28}$ Collagen type III is particularly abundant around the inflammatory cell infiltrate. ${ }^{29}$ As the inflammatory changes progress to chronic fibrosis the cellular infiltration slowly disappears leaving a matrix composed predominantly of collagen types I and III. ${ }^{29}$ In accordance with these immunohistological findings, we have shown that patients with rheumatoid arthritis have higher S-PIIINP levels than patients with inactive disease, who still present higher levels than normals. ${ }^{6}$

The correlation between S-PIIINP and the clinical signs of synovitis and the acute phase protein response (Tables 2 and 3 ) supports the assumption that the inflamed synovium is the predominant contributor to the increased S-PIIINP values in active RA. Accordingly, up to 1000 times higher PIIINP values may be demonstrated in synovial fluid than in serum. ${ }^{30}$ Significant differences were seen, however, between the serological connective 
tissue metabolites and the other clinical and serological variables during treatment with disease modifying antirheumatic drugs. The correlations between the collagen metabolites and the clinical signs of synovitis recorded in the active phase of the disease probably reflect the enhanced collagen type III formation elicited by the acute inflammation (Table $3)$. The delay in normalisation of the collagen metabolites (Table 1) may reflect continuing chronic inflammation similar to that previously reported in follow up studies of patients with acute viral hepatitis. ${ }^{31}$

In the present study S-PIIINP correlated with S-HA only in the initial active phase of synovitis (Table 3). S-HA decreased throughout the first eight months, whereas S-PIIINP increased slightly at month 4 followed by a significant decline during the next four months. These changes in circulating matrix elements accord with the temporal pattern of extracellular matrix formation in developing granulation tissue, in which hyaluronic acid dominates in the early stages followed by type III collagen proliferation. ${ }^{26} 32-34$

The S-PIIINP antigen profile in active RA and during recovery (Fig. 2) was very similar to that seen during recovery from an episode of alcoholic hepatitis, ${ }^{35}$ implying that this peptide pattern represents changes which are common to procollagen/ propeptide metabolism during non-specific acute and chronic inflammation: the Col 1-3 fraction dominates in the acute inflammatory phase. The $\mathrm{Col}$ 1-3 and the high molecular fraction are prevalent during the chonic inflammatory phase, whereas the Col 1 fraction dominates after complete remission and also in healthy individuals.

The initial S-PIIINP and S-HA were not useful as predictors of the outcome of the clinical or serological variables of inflammation. This finding supports the assumption that the serological connective tissue metabolites reflect alterations in the connective tissue metabolism caused by the inflammatory process, and not factors initiating the inflammation.

In a previous prospective pilot study we showed that normal S-RIA-PIIINP in patients with active RA indicated a good prognosis without progression of erosive joint lesions. ${ }^{6}$ The present more extensive study further substantiated this observation. In patients with normal averag S-RIA-PIIINP during the follow up new joint erosions were only recorded in one patient within the following two years. On the other hand, $44 \%$ (59\% when both radiological evaluation methods were used) of the patients who had raised average S-RIA-PIIINP values within the first eight months, and $63 \%$ of patients with raised average S-RIA-PIIINP between months 8 and 24 developed new erosions. Apparently this finding reflects a linkage between collagen fibrogenesis and matrix destructive mechanisms in the rheumatoid joints. We were not able to distinguish between: patients with and without progressive bone damages using the Fab-PIIINP or the HA assays. The explanations may be that S-Fab-PIIINP detect호 mainly propeptide degradation products and there $\frac{\bar{\alpha}}{5}$ fore is more susceptible to alterations in the meta路 bolism of circulating propeptides. S-HA in contrast with S-PIIINP shows variation in relation to physica activities (unpublished data). This may influence the S-HA values even though the sampling time was standardised.

Theoretically, the presence of aggregated IgG anc rheumatoid factors in serum could interfere directly with the assays, and C1q, which has a collagen-likê fragment, could cross react with PIIINP. We only recorded a correlation between S-RIA-PIIINP anळ total IgG and IgG rheumatoid factors at month $\Phi$ (Tables 2 and 3 ). As the recovery of added $\mathrm{Col} 1-3$ or Col 1 was not influenced by the presence of $\mathrm{IgG}$ including IgG rheumatoid factors, this correlation probably indicates that S-RIA-PIIINP, total IgG and $\mathrm{IgG}$ rheumatoid factors are all related to the inflamed synovial mass. The recovery experimentso also speak against an influence of circulating antie\& $10^{\circ}$ lagen antibodies on the S-PIIINP levels in RA These antibodies are directed mainly against co lent structural determinants present on denaturated collagens, and, in contrast with S-PIIINP, they show no correlation with disease activity in RA. ${ }^{36}$ 吕

The present study has confirmed the previously? observed suppressive effect of azathioprine on the S-RIA-PIIINP level in active RA. ${ }^{6}$ Apparently, this ${ }^{3}$ suppression does not represent a non-specific effect on protein synthesis because no differences were. observed in serum albumin between the three treatment groups. ${ }^{11} 14$ The decreased S-PIIINP levef in azathioprine non-responders may reflect an azathioprine induced specific suppression of the collagen type III synthesis elicited by acute in flammation. Immunosuppressive treatments leading to declining S-PIIINP values in treatment respon? ders have also been shown in cryptogenic fibrosing alveolitis $^{37}$ and chronic active hepatitis, ${ }^{38} 39$ bu appear not to influence the S-PIIINP level in

primary biliary cirrhosis. ${ }^{40} 41$
The importance of suppressing the S-PIIINP leve ${ }^{2}$ in chronic fibrosing conditions remains to be elucio dated. The propeptide, however, seems to be closely related to the pathogenetic processes in the inflamed synovium: RA patients with normals S-RIA-PIIINP have a favourable prognosis as $\mathrm{re}^{-}$ gards progression of joint erosions and there was $\bar{\phi}$ minimal progression of joint damage during aza $\overrightarrow{\mathbb{D}}$ thioprine treatment. 
The authors gratefully acknowledge the excellent technical assistance of N Guldhammer, A M Hildebrandt, and K Lilja. Human PIIINP. Col 1-3, and Col 1 were kindly supplied by Drs $\mathbf{J}$ and $\mathrm{L}$ Risteli. Oulu. Finland. RIA-gnost procollagen-III-peptide assays and Fab-procollagen-III-peptide assays were kindly provided by Hoechst A G. Frankfurt. Germany. This work was supported by the Danish Rheumatism Association. grant No 233-469, the Henny and Helge Holgersen Foundation, the Gustav the Vth 80 years Foundation, and the Signe and Reinhold Sunds Foundation.

\section{References}

1 Rohde H. Vargas L. Hahn E. Kalbfleisch H. Bruguera M, Timpl R. Radioimmunoassay for type III procollagen peptide and its application to human liver disease. Eur J Clin Invest 1979: 9: 451-9.

2 Rohde H. Langer I, Kricg T. Timpl R. Serum and urine analysis of the aminoterminal procollagen peptide type III by radioimmunoassay with antibody Fab fragments. Coll Relat Res 1983; 3: 371-9.

3 Laurent U B G. Tengblad A. Determination of hyaluronate in biological samples by a specific radioassay technique. Anal Biochem 1981; 109: 386-94.

4 Engström-Laurent A. Laurent U B G, Lilja K, Laurent T C. Concentration of sodium hyaluronate in serum. Scand J Clin Lab Invest 1985; 45: 497-504.

5 Ristcli L. Ristcli J. Radioimmunoassays for monitoring connective tissue metabolism. Rheumatology 1985: 10: 216-45.

6 Hørslev-Petersen K. Bentsen K D. Junker P. Lorenzen I. Serum aminoterminal type III procollagen peptide in rheumatoid arthritis. Arthritis Rheum 1986; 29: 592-9.

7 Hatahara T, Igarashi S. Funaki N. High concentrations of $\mathrm{N}$-terminal peptide of type III procollagen in the sera of patients with various cancers, with special reference to liver cancer. Gann 1984: 75: 130-5

8 Engström-Laurent A. Hällgren R. Circulating hyaluronate in rhcumatoid arthritis. Ann Rheum Dis 1985; 44: 83-8.

9 Krieg T. Langer I. Gerstmeier H, et al. Type III collagen aminopropeptide levels in serum of patients with progressive systemic scleroderma. J Invest Dermatol 1986: 87: 788-91.

10) Engström-Laurent A. Feltelius N. Hällgren R. Wasteson A. Raised serum hyaluronate levels in scleroderma: An effect of growth factor induced activation of connective tissuc cells? Ann Rheum Dis 1985; 44: 614-20.

11 Halberg P. Bentzon M W. Crohn O. et al. Double-blind trial of levamisole, penicillamine, and azathioprine in rheumatoid arthritis. Dan Med Bull 1984: 31: 4(1)3-9.

12 Ingeman-Niclsen $M$, Halskov $O$. Hansen $T$ M. Halberg $P$, Stage $P$. Lorenzen I. Clinical synovitis and radiological lesions in rhcumatoid arthritis. Scand J Rheumatol 1983; 12: 237-40.

13 Bentzon M W. Gad I. Halberg P, et al. Influence of previous gold treatment and other patient variables on outcome of treatment with disease modifying anti-rheumatic drugs (DMARD) in patients with rheumatoid arthritis. Clin Rheumatol 1986; 5: 39-48.

14 Bentzon M W. Gad I, Halberg P. Halskov O. Lorenzen I. Acute phase proteins and clinical synovitis activity in paticnts with rhcumatoid arthritis. Clin Rheumatol 1987: 6: 226-32.

15 Ropes M W. Bennett G A. Cobb S, Jacox R, Jessar R A. 1958 revision of diagnostic criteria for rheumatoid arthritis. Bull Rheum Dis 1958: 9: 175-6.

16 Cooperating Clinics Committec of the American Rheumatism Association. A seven day variability study of 499 patients with peripheral rheumatoid arthritis. Arthritis Rheum 1965; 8: 31)2-34.

17 Steinbrocker O. Traeger C H. Batterman R C. Therapeutic critcria in rhcumatoid arthritis. JAMA 1949: 140: 659-62.

18 McCarthy D J. Methods for evaluating rheumatoid arthritis. In: Hollander H L. McCarthy D L. eds. Arthritis and allied conditions. 8th ed. Philadelphia: Lea and Febiger. 1972: 419.
19 Nordfang O, Høier-Madsen M, Halberg P, Licberkind J. A new radioimmunoassay for IgM and IgG rheumatoid factors, based on double antibody method. J Immunol Methods 1981; 47: 87-97.

20 Jans H, Halberg P, Lorenzen I. Circulating immune complexes in rheumatoid arthritis with extra-articular manifestations. Scand J Rheumatol 1983: 12: 215-8.

21 Myllylä G, Vaheri A. Penttinen K. Detection and characterization of immune complexes by the platelet aggregation test. II Circulating immune complexes. Clin Exp Immunol 1971; 8: 399-408.

22 Larsen A, Dale K. Eek M. Radiographic evaluation of rheumatoid arthritis and related conditions by standard reference films. Acta Radiol /Diagn/ (Stockh) 1977; 18: 481-91.

23 Sicgel S. Nonparametric statistics for the behavioural sciences. London: McGraw-Hill Kogakusha, 1956: 1-312.

24 Hahn E G. Blood analysis for liver fibrosis. J Hepatol 1984; 1: 67-73.

25 Hørslev-Petersen K. Kim K Y. Olsen B, et al. Serum aminoterminal type III procollagen peptide reflects collagen type III synthesis in granulation tissuc in rats. Scand $J$ Rheumatol [Suppl] 1986: 59: 85.

26 Gay S, Gay R E. Miller E J. The collagens of the joint. Arthritis Rheum 1980; 23: 937-42.

27 Eyer C R, Muir H. Type III collagen: a major constituent of rheumatoid and normal synovial membrane. Connect Tissue Res 1975; 4: 11-16.

28 Lovell C R. Nicholls A C. Jayson M I V. Bailey A J. Changes in the collagen of synovial membrane in rheumatoid arthritis and effects of D-penicillaminc. Clinical Science and Molecular Medicine 1978: 55: 31-40.

29 Scott D L. Salmon M. Walton K W. Reticulin and its related structural connective tissuc proteins in rhcumatoid synovium. Histopathology 1984; 8: 469-79.

30) Gressner A M. Neu H-H. N-terminal procollagen peptide and $\beta_{2}$-microglobulin in synovial fluids from inflammatory and non-inflammatory joint diseases. Clin Chim Acta 1984; 141: 241-5.

31 Bentsen K D, Hørslev-Petersen K. Junker P. Juhl E. Lorenzen I. Serum aminoterminal procollagen type III peptide in acute viral hepatitis. A long term follow-up study. Liver 1987; 7: $96-105$.

32 Dorner R W. Scleroderma skin-conflicting mucopolysaccharide data reflect stages in connective tissue maturation. J Rheumatol 1980); 7: 128-9.

33 Hansen T M. Garbarsch C. Helin G. et al. Proteoglycans, DNA, and RNA in rat granulation tissue, skin, and aorta. Biochemical and histological studies. Acta Pathologica et Microbiologica Scandinavica. Section A. Pathology 1980): 88: 143-50.

34 Gay S, Viljanto J. Rackallio J, Penttinen R. Collagen types in carly phases of wound healing in children. Acta Chir Scand 1978: 144: 205-11.

35 Niemelä O, Risteli L. Sotaniemi E A. Risteli J. Aminoterminal propeptide of type III procollagen in serum in alcoholic liver discase. Gastroenterology 1983; 85: 254-9.

36 Stuart J M. Huffstutter E H, Townes A S. Kang A H. Incidence and specificity of antibodics to types I. II. III. IV, and V collagen in rheumatoid arthritis and other rheumatic diseases as measured by ${ }^{125}$ I-radioimmunoassay. Arthritis Rheum 1983; 26: $832-40$.

37 Kirk J M E, Bateman E D, Haslam P L, Laurent G J, Turner-Warwick M. Scrum type III procollagen peptide concentration in cryptogenic fibrosing alveolitis and its clinical relevance. Thorax 1984: 39: 726-32.

38 Ballardini G. Faccani A. Bianchi F B. et al. Steroid treatment lowers hepatic fibroplasia, as explored by serum aminoterminal procollagen III peptide, in chronic liver disease. Liver 1984; 4: $348-52$.

39 McCullough A J. Stassen W N, Wiesner R H. Czaja A J. Serum 
type III procollagen peptide concentrations in severe chronic active hepatitis: relationship to cirrhosis and disease activity. Hepatology 1987; 7: 49-54.

40) Savolainen E-R, Miettinen T A, Pikkarainen P, Salaspuro M P, Kivirikko K I. Enzymes of collagen synthesis and type III procollagen aminopropeptide in the evaluation of D- penicillamine and medroxyprogesterone treatments of primary biliary cirrhosis. Gut 1983; 24: 136-42.

41 Weigand K, Zaugg P-Y, Frei A, Zimmerman A. Long-term follow-up of serum $\mathrm{N}$-terminal propeptide of collagen type III levels in patients with chronic liver disease. Hepatology 1984; 4: 835-8. 